\title{
Participatory commodity networking: An integrated framework for Fairtrade research and support
}

\author{
Jennifer Keahey, Laura T Raynolds, Sandra Kruger and Andries du Toit
}

\begin{abstract}
This article discusses the potential for humanizing production and trade relations by extending action research to multilateral commodity networks. Participatory action research and Fairtrade certification both promote social justice, but the first faces difficulties in terms of scalability, while the second experiences challenges in terms of producer support. As conventional research has failed to deliver methods for improving services, we worked with small-scale farmers in South Africa's rooibos tea industry to meet this gap. Responding to producer concerns regarding market and certification access, we conducted a participatory research, training, and networking program to establish a farmer leadership network within the rooibos industry. Despite the challenges involved in advancing participation in an arena marked by complex power relations, our work helped stakeholders establish trust, improve knowledge, and begin addressing issues. By incorporating commodity network analysis into action research methodology, our model facilitates both community and organizational development, offering a multilateral framework for collaborative inquiry.
\end{abstract}

\section{Introduction}

The global fair trade ${ }^{1}$ movement promotes social justice in trade, primarily through a product certification system governed by Fairtrade International. Certification provides producers with access to buyers offering minimum price guarantees, stable contracts, and premiums for development. However, marginal groups have experienced uneven impacts (Raynolds \& Bennett, 2015). In postcolonial Africa, small-scale farmers find it difficult to meet Fairtrade requirements due to limited infrastructure (Tallontire, 2015); and in post-apartheid South Africa, producers of color are hindered by stark racial disparities (Keahey, 2015). While few studies have examined the question of support, this matter is salient and timely as Fairtrade International is transferring governance of producer services to its regional affiliates.

In 2010, we conducted a one-year project with small-scale farmers in South Africa's rooibos tea industry. Linking participatory action research (PAR) with commodity network analysis, we generated a participatory commodity networking research (PCNR) approach to producer support. This article presents our framework, explains how it was operationalized, and shares key findings and reflections. Similarly to PAR, our work reconnects theory with practice via a process of engaged inquiry (Chevalier \& Buckles, 2013). The approach presented in Figure 1 provides: (1) a research platform to identify 
producer barriers; (2) a training platform to strengthen leadership capacity; and (3) a networking platform for multilateral engagement. Thus, PCNR facilitates community and organizational development (Selener, 1997). It supports communities by working with farmer leaders to meet local gaps in support; and it expedites organizational development by linking leaders to the wider commodity network where structural solutions to identified challenges may be pursued.

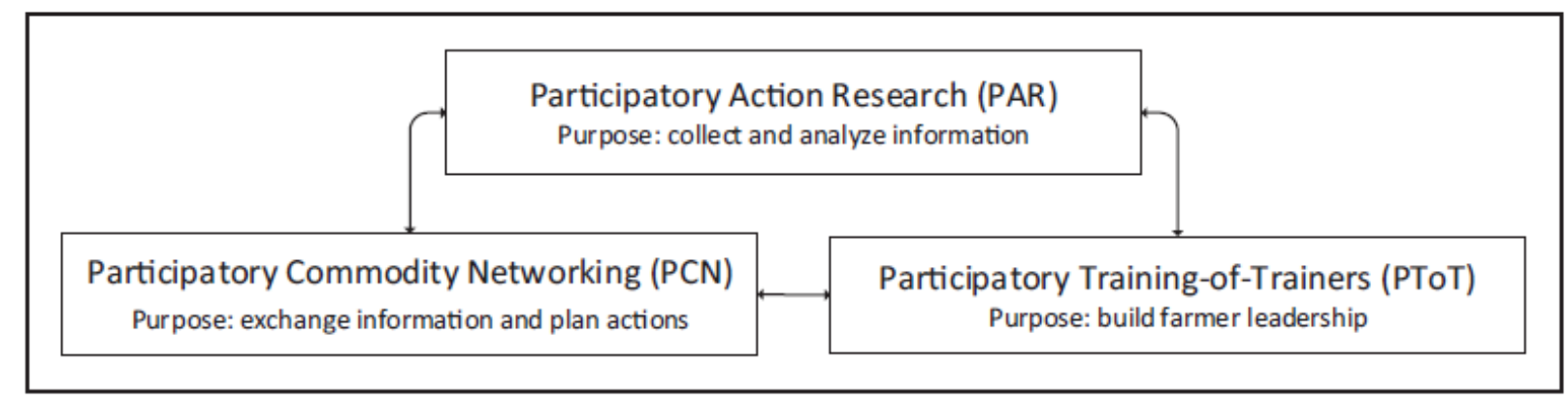

Figure I. PCNR framework.

Working with community-based farmer leaders during a period of Fairtrade market uncertainty, we examined producer experiences and identified gaps in support. We found that the communities involved in our project had experienced inconsistent support and possessed poor knowledge of Fairtrade certification. These issues fueled a crisis that led to the demise of a large rooibos cooperative, further marginalizing farmers in markets. PCNR opened a critical space for multidirectional learning. We employed reflexive dialogue and consensusbuilding activities to democratize engagement, empowering farmer leaders to gain a voice within the rooibos network. However, we were unable to surmount broader structural barriers and failed to secure funding to extend outcomes. These issues replicated the imbalances we sought to address, illustrating the limits of our approach as well as the extent of challenges facing work of this kind. Our experience may offer insight for researchers who are interested in "linking participatory approaches to wider, and more difficult, processes of democratization" (Mohan, 2001, p. 166).

\section{Conceptualizing the approach}

Table 1 details our conceptual toolbox. The theories and methods presented here meet recognized gaps in knowledge and praxis while sharing an underlying structure of values in common. First, PAR emphasizes social justice in research, but faces barriers in terms of scalability. There is a need to "address issues of complexity" related to alternative forms of development and globalization without sacrificing PAR's commitment to collective and engaged inquiry (Chevalier \& Buckles, 2013, p. 5). Second, Fairtrade "represents an important form of alternative organizing" in multilateral networks, but this system struggles to support marginal producers (Raynolds \& Keahey, 2014, p. 165). Third, commodity studies tend to ignore complex power dimensions, hindering the development of informed policies (Phillips, 2014). PCNR responds to these gaps by: (1) extending PAR to the 
commodity network; (2) providing a reflexive framework for capacity building; (3) instituting a platform for multidirectional learning; and (4) identifying underlying barriers to participation.

Participatory action research. Recognizing the situated nature of knowledge, action researchers eschew claims of objectivity in favor of relevance. However, standards are rigorous and validity is ensured by meeting "the test of action" (Brydon-Miller, Greenwood, \& Maguire, 2003, p. 25). Action research has proven capable of generating striking innovations as it offers a platform for linking local and expert knowledge (Hoffmann, Probst, \& Christinck, 2007). In particular, PAR calls for equal participation in project planning, monitoring, and evaluation (Selener, 1997). Critical applications have employed the lens of white privilege (EAC, 2005) and postcolonial power (Schurr \& Segebart, 2012) to address inequalities in research and practice.

Despite these benefits, PAR remains underutilized as it is difficult to implement in arenas where hierarchical and linear protocols inform practice. PCNR straddles these tensions, in part, by using the capability approach to assess knowledge, skills, and experiences.

Table I. PCNR toolbox.

\begin{tabular}{|c|c|c|}
\hline Tools & Ideal purpose & Material purpose \\
\hline \multicolumn{3}{|c|}{ Participatory action research } \\
\hline PAR & $\begin{array}{l}\text { Democratize the research } \\
\text { process in order to facilitate } \\
\text { social justice }\end{array}$ & $\begin{array}{l}\text { Involve stakeholders in } \\
\text { research, training, and } \\
\text { networking }\end{array}$ \\
\hline Human capabilities & $\begin{array}{l}\text { Expand indicators for a more } \\
\text { holistic understanding of } \\
\text { capacity }\end{array}$ & $\begin{array}{l}\text { Identify producer resources, } \\
\text { capabilities, and needs }\end{array}$ \\
\hline \multicolumn{3}{|c|}{ Participatory training-of-trainers } \\
\hline Holistic learning & $\begin{array}{l}\text { Connect ideas with experiences } \\
\text { and integrate different } \\
\text { knowledges }\end{array}$ & $\begin{array}{l}\text { Engage critical thinking, } \\
\text { reflexive dialogue, and } \\
\text { consensus building }\end{array}$ \\
\hline Training-of-trainers & $\begin{array}{l}\text { Ensure learner-centered and } \\
\text { performance-based training }\end{array}$ & $\begin{array}{l}\text { Build leadership capacity } \\
\text { and assess impacts }\end{array}$ \\
\hline $\begin{array}{l}\text { Commodity network } \\
\text { analysis }\end{array}$ & $\begin{array}{l}\text { Participatory commodity networking } \\
\text { Capture multilateral linkages } \\
\text { from within a unifying } \\
\text { framework }\end{array}$ & $\begin{array}{l}\text { Clarify commodity sector } \\
\text { challenges and } \\
\text { opportunities }\end{array}$ \\
\hline Theories of power & $\begin{array}{l}\text { Integrate multifaceted political } \\
\text { analysis into commodity } \\
\text { research }\end{array}$ & $\begin{array}{l}\text { Uncover horizontal as well } \\
\text { as hierarchical power } \\
\text { dimensions }\end{array}$ \\
\hline
\end{tabular}

PCNR: participatory commodity networking research; PAR: participatory action research. 
Promoting a more holistic understanding of well-being, this approach is designed to capture basic capabilities, like access to housing, as well as broader dimensions, like the ability to participate in public life (Sen, 2004). However, specific measurements are determined by stakeholders in the field. The capabilities approach enables PCNR participants to develop a set of baseline indicators at project onset. These indicators are reflexively used to: (1) problematize barriers; (2) determine actions; (3) monitor and evaluate performance; and (4) assess outcomes.

Participatory training-of-trainers. Fairtrade International emphasizes empowerment through capacity building as a primary strategy for improving trade relations (WFTO \& FTI, 2009). Yet, few studies have examined this topic. This issue is of import as training may silence different ways of knowing (Keahey, 2016). Colonial regimes used education as an instrument for control, and assumptions of Western superiority remain embedded in postcolonial education and development, reproducing the conditions for oppression (Freire, 1997). PCNR responds to this problem within the context of leadership training. While it engages the performance protocols required for accreditation, PCNR places critical thinking, reflexive dialogue, and consensus building at the center of the learning process. These holistic learning activities emphasize knowledge generation over knowledge transfer, enabling participants to explore ideas and challenge hegemonic assumptions about expertise (Mkabela \& Luthuli, 1997).

Participatory commodity networking. Commodity chain research examines how global markets impact local production practices (Gereffi, 1994). Within this tradition, value chain scholars study how producers seek to improve their market position by adding value to their products, either by securing certifications or by assuming more sophisticated production roles (Gibbon \& Ponte, 2005). Yet, product upgrading may stymie diversification (Smith, 2009) and increase the vulnerability of poor producers (Ponte \& Ewert, 2009). Moreover, many studies fail to examine power imbalances or assume a top-down view that ignores local cleavages based on class, race, and gender (Phillips, 2014). In contrast, commodity network analysis uses ethnographic methods and a network orientation to clarify the complex webs of action found in certification practices (Raynolds, 2009). By incorporating multiple theories of power into analysis, researchers may capture details related to:

(1) managerial organization; (2) political engagement; and (3) social inequalities. PCNR uses commodity network analysis to identify receptive points of action and guide networking activities that enable farmer leaders to witness and participate in governance.

\section{The research arena}

Fairtrade dimensions. Fairtrade has become a multi-billion dollar certification initiative that encompasses 1.4 million farmers and workers in 74 countries across Africa, Asia, and Latin America (Fairtrade International, 2014). In Africa, the number of certified producer organizations doubled between 2006 and 2012 (Fairtrade International, 2013). While most Fairtrade products are sold in the Global North, South African, and Kenyan affiliates have established domestic markets for certified goods in an effort to transcend the colonial 
pattern of African production for Northern consumption (Keahey, 2015). To support regional expansion, Fairtrade International is decentralizing key functions, with Fairtrade Africa $^{2}$ assuming governance of African producer services in 2013. In South Africa, these shifts are occurring alongside the entry of other ethically labeled items, creating new markets that integrate global and local networks and values (Hughes, MacEwan, \& Bek, 2015).

These shifts demonstrate Fairtrade's potential, but critiques have emerged. In particular, studies show that certifiers can reinforce inequalities by ignoring local power dimensions (Nelson \& Martin, 2015). Rather than exploring solutions to these concerns, the scholarly literature has become entrenched in analytical debates regarding the efficacy of certification (Naylor, 2014). Yet, the decentralization of producer services opens opportunities for producers to become involved in designing responsive support mechanisms; and action research is well suited to this task.

The rooibos network. In South Africa, white-owned estates produce over 90\% of the rooibos destined for sale (Ives, 2014). The remaining tea is cultivated by coloured (mixed-race) farmers who typically operate on small plots of rented land, in isolated areas with poor infrastructure. Whereas, hired-labor estates are embedded within an established chain that supplies domestic and export markets, small farmer organizations operate at the margins of the industry. At research outset, small-scale farmers lacked representation within the South African Rooibos Council, the umbrella industry platform. Whereas, new producer organizations generally sold their tea to the nearest processing firm, established groups secured certifications to access more lucrative export markets. Such moves involved risk: among the five small farmer organizations producing rooibos at research outset, two were newly formed and uncertified; two held Fairtrade and organic certifications; and the fifth and largest cooperative was collapsing due to a recent loss in certifications.

The action research team. PCNR engagement was led by: (1) three U.S.-based fair trade scholars, one of whom was the lead field researcher in South Africa; (2) a South African scholar with expertise in agrarian poverty; and (3) a South African training provider specializing in standards and certifications. During the first phase, the action research team grew to include 13 farmer leaders who were democratically elected by their communities. Representing seven community groupings, these leaders actively informed the development of subsequent project stages, while their communities remained peripherally involved. The composition of our team was reflective of the power dynamics prevalent in post-apartheid South Africa: the lead investigators were all white and operating from a position of class privilege, while all but one of the farmer leaders were coloured. ${ }^{3}$ Four leaders had access to computers but most lived in poverty, with some lacking such basic amenities as running water. Apart from a labor organizer and a few Fairtrade actors, all of the experts who engaged with the leaders were white South Africans. Gender dynamics were more balanced: three of the five lead investigators and nearly half of the leaders were women. 
Action research scholars note that privileged actors experience difficulties in terms of "staying in the inquiry" when examining power (EAC, 2005, p. 60). The lead field researcher took responsibility for addressing imbalances within the action research team and broadly sought to stay in the inquiry by: (1) living almost entirely in coloured communities; (2) paying the leaders for their work and hosts for room and board; and (3) initiating talks about power in a receptive environment. The lead trainer supported these efforts by spending time in the communities, developing relationships with the leaders, and enabling them to dialogue with industry and organizational stakeholders in private and informal settings.

Table 2. PCNR operationalization.

\begin{tabular}{|c|c|c|c|}
\hline Project phase & Activities & Methods & Products \\
\hline $\begin{array}{l}\text { I. Community } \\
\text { entry }\end{array}$ & $\begin{array}{l}\text { - Map rooibos network } \\
\text { - Facilitate capabilities } \\
\text { workshops } \\
\text { - Hold leadership } \\
\text { elections }\end{array}$ & $\begin{array}{l}\text { - Document analysis } \\
\text { - Unstructured } \\
\text { interviews } \\
\text { - Participant } \\
\text { observation }\end{array}$ & $\begin{array}{l}\text { - Map of commodity } \\
\text { network } \\
\text { - Farmer capabilities } \\
\text { workbooks } \\
\text { - Baseline capabilities } \\
\text { indicators }\end{array}$ \\
\hline $\begin{array}{l}\text { II. Leadership } \\
\text { building }\end{array}$ & $\begin{array}{l}\text { - Facilitate multi-day } \\
\text { PToT sessions } \\
\text { - Conduct PAR } \\
\text { fieldwork } \\
\text { - Begin commodity } \\
\text { networking }\end{array}$ & $\begin{array}{l}\text { - Participant observation } \\
\text { - Semi-structured } \\
\text { interviews } \\
\text { - Reflexive dialogue }\end{array}$ & $\begin{array}{l}\text { - Toolbox of training } \\
\text { material } \\
\text { - Guide to } \\
\text { certifications }\end{array}$ \\
\hline $\begin{array}{l}\text { III. Information } \\
\text { exchange }\end{array}$ & $\begin{array}{l}\text { - Facilitate policy } \\
\text { seminar } \\
\text { - Conduct farmer } \\
\text { workshops } \\
\text { - Evaluate outcomes } \\
\text { and materials }\end{array}$ & $\begin{array}{l}\text { - Participatory } \\
\text { data analysis } \\
\text { - Consensus building } \\
\text { - Evaluation surveys }\end{array}$ & - Executive summary \\
\hline
\end{tabular}

PCNR: participatory commodity networking research; PAR: participatory action research; PToT: participatory training-of-trainers.

\section{Operationalizing the approach}

We invited all small-scale rooibos farmers into the project and participants included the members of four organizations. 4 of the 300 farmers operating at that time, 246 resided in participating communities. In addition to the close involvement of 13 farmer leaders, 203 farmers attended workshops. We were unable to include producers in creating the initial research proposal due to a lack of funding, but actions were developed in the field. To balance PAR precepts with technical constraints, we sought to deepen stakeholder participation over the course of the project. Thus, farmer leaders increasingly assumed control of PCNR planning and engagement. Table 2 outlines our activities and methods which were conducted during overlapping phases.

Community entry. We began by drawing from our previous work in rooibos to map the commodity network. During entry, the lead field researcher conducted unstructured 
interviews with farmers and higher level representatives to update our knowledge of rooibos arrangements and relations. This enabled us to locate new small farmer organizations and determine receptive entry points within the commodity network. During several community visits, we dialogued with farmers and solicited ideas for engagement. Most producers asked us to work directly in their communities as many hamlets were located at distance from one another over rough terrain. Using the metaphor of a hand, one informant stated that rooibos support largely was directed to the palm where cooperatives were located, rather than to farmers in the more remote fingers. By holding capabilities workshops in multiple community groupings, farmers were able to participate in their own areas, while cooperative staff attended in central locations.

We used participatory rural appraisal techniques (Chambers, 1994) and a general list of capabilities (Nussbaum, 2011) to develop capability workshop activities. In addition to mapping community resources and needs, farmers mapped capabilities. These interactive workshops achieved three objectives. First, participants discussed their needs and determined participatory training-of-trainer (PToT) topics. Second, participants informed the development of baseline indicators. Third, each workshop culminated in elections, enabling farmers to establish a grassroots leadership network as they had requested. 5 The lead trainer and field researcher (both female) suggested a policy of electing one male and one female leader in each community grouping to reflect women's growing involvement in rooibos. The gender clause was well received in most areas and 6 of the 13 elected leaders were women. Not only did male leaders support the entry of women into leadership, female leaders found their involvement to be particularly empowering. As Helen ${ }^{6}$ stated:

I was scared to go to the first ToT, because I thought I would say something stupid, but then [the trainers] taught me that it is okay to speak because there are no wrong answers. Now I have so much confidence, I can do anything. I can even speak English!

Leadership building. During the second phase, the farmer leaders participated in three multiday training-of-trainer workshops and in additional sessions held during fieldwork and networking. PToT involved industry and organizational actors and covered subjects related to: (1) rooibos production; (2) markets and certifications; (3) management and leadership; and (4) research and analysis. Sessions were conducted in Afrikaans and translators were present when English was spoken. While the lead trainer organized PToT, the lead field researcher was a participant observer and facilitated sessions related to research and analysis. Not only did the workshops incorporate holistic learning activities, the leaders determined the training trajectory and helped develop material, including a farmers' guide to standards and certifications. These products included booklets and exercises on topics requested by farming communities.

PAR fieldwork was conducted over the course of two months at protect mid-term. The farmer leaders prepared by: (1) taking a census of their communities; (2) completing research training; and (3) helping develop interview questions. During fieldwork, the leaders 
generated a stratified random sample ${ }^{7}$ to incorporate female and male respondents, various age cohorts, and places of residence. Each leader first acted as a respondent then worked as a translator during interviews conducted in their area. After witnessing interviews facilitated by the lead field researcher, most leaders chose to conduct subsequent interviews. Private interviews were then held with each leader to explore sociopolitical dimensions, setting the stage for data analysis.

Leadership building activities enabled the leaders to connect abstract knowledge with concrete experiences. By engaging in philosophical discussions about research, training, and networking while conducting these processes, the action research team explored different ways of knowing and doing; and reflexively incorporated insights into next-stage actions. As the leaders gained expertise, they expressed a desire for greater responsibility and control. After completing farmer interviews, Anton told the lead field researcher:

You have to include us in the data analysis. We are leaders of our communities. We should be able to decide what gets written about us...please teach us more about research ethics so we can decide how to share the information together.

Information exchange. Networking occurred throughout the project, but we deepened these activities during the third phase to stimulate multilateral exchanges. During entry, we used commodity network analysis to problematize networking activities that began during the second phase. At this point, networking primarily involved:

(1) dialoguing with experts at training sessions; (2) touring two processing firms; (3) attending industry events organized by the South African Rooibos Council; and (4) participating in Fairtrade South Africa's annual general meeting. The Fairtrade conference provided insight into certification governance, whereas Rooibos Council forums enabled farmer leaders to learn about industry governance.

During the third phase, we hosted a policy seminar at a university where farmer leaders met with industry, organizational, and academic actors to share action research findings. The leaders prepared for the seminar by conducting a participatory data analysis session to determine key findings. Via a theories-of-power activity, the lead field researcher worked with the leaders to differentiate between issues related to managerial practices, political processes, and social inequalities. ${ }^{8}$ At the policy seminar, the leaders conducted presentations and led breakout sessions with higher level actors to problematize solutions to identified issues. The Rooibos Council session discussed how to create a platform for small-scale farmers to communicate their interests within the industry; the Fairtrade session examined how to strengthen relations with small-scale farmers, including strategies for improving support; and an environmental session discussed strategies to link farmers to a biodiversity campaign. The seminar was structured to challenge traditiona lpower relations. As the leaders assumed positions of authority, higher level actors recognized them as credible sources of knowledge empowering us all. When discussing the outcomes of the seminar, Dirk said: 
People from the industry came to listen to us speak. They are interested in learning what farmers need. I'm going to go home and tell my community that the industry wants our rooibos.

In addition to facilitating information exchanges with experts, the third phase also brought information back into the communities. Leading this process, the farmer leaders drew from the toolbox of training material to design and facilitate farmer workshops in their areas. PCNR subsequently ended with the leaders conducting evaluation surveys. The following two sections focus on findings and impacts. Whereas, the first section presents fieldwork findings, the second analyzes the outcomes of our experience.

\section{Research findings}

Producers' experiences with Fairtrade. This project was carried out during a period of disarray caused by the recent decertification of a large rooibos cooperative. Having gained organic certification in 1999 and Fairtrade certification in 2005, this group had established a packaging venture with a smaller cooperative and a local contract packager (Raynolds \& Ngcwangu, 2010). Despite its initial promise, the Fair Packers venture collapsed in 2009 for a variety of reasons. First, Fair Packers was expected to meet market requirements without developmental assistance, but its staff was comprised of farming family members who lacked technical capacity. Second, the larger cooperative went into considerable debt, promising future tea sales to meet its share of the start-up costs. Third, Fair Packers failed to garner sufficient profit due to the unexpected entry of rooibos estates into Fairtrade markets.

While the small cooperative partner survived the dissolution of the Fair Packers agreement with substantial external assistance, the larger cooperative unraveled and lost its certifications in 2009. Members responded to the crisis by electing a new board, causing communities to splinter into factions. A group of farmers left the cooperative and pooled resources to establish a new organization under the leadership of former management. In 2010, this new cooperative secured Fairtrade and organic certifications, regaining access to global buyers. Meanwhile the larger group found it difficult to sell decertified tea and incoming management lacked the skills to seek recertification. Unable to pay its members for their tea, the cooperative underwent legal action and was liquidated in 2011. This tumultuous backdrop significantly shaped the action research process. In particular, the emerging leadership network worked to resolve tensions by sharing reliable information and by calling for farmers to "stand together" during tense discussions.

Gaps in support. Fueling producer uncertainty, we found that most farmers possessed little understanding of certifications. Capabilities workshop participants had basic knowledge of organic standards, but few could provide information regarding Fairtrade certification and markets. These findings were substantiated during interviews when we asked farmers to share their knowledge about certifications and buyers. In communities that had participated in certified markets, most respondents could articulate at least one organic standard, but only a third were able to state one Fairtrade standard. Apart from those in managerial positions, 
virtually no respondents could name any Fairtrade buyers. Farmers expected cooperative staff to manage marketing, but most wanted to learn about certifications and all desired access to reliable market information.

Fairtrade provides certification advisory services to producer organizations, but otherwise relies upon existing networks to deliver training and support. In South Africa, governmental agencies, nongovernmental organizations, and private firms provide services to producers. However, the availability and quality of services was variable. Farmers stated that programs generally were designed without their input and often progressed with minimal engagement. Few projects were coordinated. We found that those residing near cooperative headquarters had somewhat greater access to services and experienced slightly lower levels of poverty than those living in remote outstations. However, cooperative staff also lacked access to the training needed to maintain certifications. We addressed these issues by responding to producer requests for us to build leadership capacity directly within the communities rather than through existing cooperative structures. This led to positive outcomes but also stymied the ability of the leaders to maintain their platform once the project came to an end.

\section{Action research reflection}

Participation and empowerment. PCNR helped advance Fairtrade's empowerment agenda by supporting the expansion of farmer leadership within the rooibos network. However, our work did not entirely transcend a top-down model as we were unable to involve stakeholders in all aspects of our work. We navigated tensions related to participation and scalability by straddling community and organizational approaches to action research (Selener, 1997). First, we responded to farmer requests for training by working to build expertise within participating communities. Second, we responded to farmer requests for political representation by working to bring leaders into higher level organizations. In the words of one farmer at a capabilities workshop, "we have a problem with the South African Rooibos Council...we are not heard. They must come to [our village] and listen themselves to our proposal." Given the geographic distances between farming communities, we could not bring the Council to the farmers, but we could bring leaders into the Council by prioritizing the quality rather than quantity of participation (Neef \& Neubert, 2011).

Some of the farmer leaders initially were nervous about participating in the project. 9 Whereas, training helped build capacity and confidence, research and networking extended knowledge and ties. As the leaders connected to different groups, they expressed an interest in pursuing broader collaborations. For example, at project inception, most small farmers were disgruntled with white estate farmers due to the entry of estates into Fairtrade rooibos markets; but by project end, the farmer leaders wanted to collaborate with this group. After listening to estate farmers speak at a Rooibos Council event, Frank said, "I now know they have even bigger problems than us, but they are the same problems so we should be working together to find solutions." 
Finally, the farmer leaders drove information exchanges during the third phase and found these activities to be empowering. Reflecting on her role in the policy seminar, Helen wrote, "people actually listened to what I had to say and now my confidence is higher than ever." Third-stage activities also helped to legitimatize the leaders within the industry, with one of the leaders joining the Rooibos Council board at project end. Finally, project activities helped to resolve local conflicts related to Fairtrade decertification as the leaders worked to share information and improve understanding. Over time, farmers began to view the leaders as a source of support. At the end of a community workshop facilitated by two leaders, one farmer stated:

It is amazing to see how these leaders have grown from the first time that you were here. Please do not stop now. They need to continue with this type of training as it is only benefiting them and the community.

Power and identity. Addressing internal power dynamics was uncomfortable yet rewarding. For example, PToT sessions occurred in a small town where racial segregation remained a way of life. During the first session, we scheduled dinner at a restaurant and invited industry actors to join us, but upon seating ourselves we became racially segregated. The lead author moved to a table of farmer leaders and asked if she could join. This interruption caused discomfort as it made visible underlying power dynamics. It reflected the white privilege of the lead author, who possessed the power to interrupt, as well as the privilege of the foreigner who could more readily transcend cultural norms. Now seated across from one another, Bernadine and the lead author spent an uncomfortable meal together. Yet, each persisted in communicating across barriers of race, culture, and language. Later, both admitted to feeling exhausted but exhilarated. This mutual willingness to stay open to discomfort helped to shift project relations before traditional patterns had become concretized. As our engagement progressed, other members of the action research team had similar experiences that helped transform how we perceived ourselves and what we wanted to achieve. In Anna's words, "when we came to the first ToT, we didn't really know each other at all. Now, we are like a family. We like each other and we help each other and we are good friends."

Similarly to other action researchers who have studied power, we found that it was impossible to achieve "the 'right' perceptions about whiteness, race, and dominating systems of power" (EAC, 2005, p. 60). Of the various dynamics that we explored, the topic of race was the most difficult to navigate; and it was not only the white facilitators who felt discomfort. The farmer leaders were united and vocal about the negative impacts of class inequality, both in private and in public. However, they were ambivalent and divided when talking about race and avoided this topic entirely in more public settings. Not only did the leaders fail to arrive at consensus on questions pertaining to race, they were divided about the "right" language to use for their racial identity. We employ "coloured" because the majority voted in favor of it. However, those who were more vocal about racial inequalities 
disliked this official term and either preferred "black" to express solidarity with other South Africans of color or the colloquial phrase "bruin mense."10

Finally, ensuring an enabling environment was essential to internal relations, but significantly more challenging to realize in large venues outside of our control. When reviewing the first PToT session, Arthur wrote, "everyone is involved and the atmosphere created is one that encourages participation." Bernadine offered a similar sentiment by stating, "the way the workshops were conducted just gave me courage to tackle problems." In contrast, large networking events tended to reinforce barriers. At industry events, white experts and estate farmers dominated discussions with facilitators making no effort to ensure broader participation. Apart from a few breakout sessions where the leaders were encouraged to participate, the Fairtrade conference largely was dominated by white experts who spoke in English. As the following section discusses, PCNR established a foundation for extending participation within the rooibos network, pointing to the potential of our approach. Yet, we lacked the time and resources to deepen our engagement, illustrating the challenges facing such work.

Lessons learned. Our engagement taught us several lessons, particularly in terms of research and networking. First, we failed to involve the farmer leaders in third-stage interviews with network representatives. Our decision to maintain a farmer-first focus by interviewing industry and organizational actors during the final project stage was sound. However, funding shortages and scheduling conflicts prevented us from including the leaders in this final round of data collection. While they were involved in designing the interviews, they should have led this process; thus their involvement should be budgeted for in future applications. Second, we were unable to address technological barriers to communication. Most leaders lacked computer access and some lived without phones, making it challenging to exchange information and build ties. Inequalities in terms of key resources served to reinforce the imbalances that our work sought to ameliorate.

Participatory methods require an ongoing process that is guided by sustained dialogue (Nemeroff, 2008). PCNR met the initial test of action. However, we were unable to secure funding for a multiyear project that was designed to deepen and extend engagement. Since this time, we have struggled to navigate competing academic and professional obligations and the farmer leaders have experienced changes in terms of institutional arrangements, including the closure of South Africa's largest rooibos cooperative. As we worked within the communities rather than through the cooperatives, many leaders lacked the institutional resources needed to maintain their roles after our departure. If scholars, professionals, and farmers are to effectively collaborate over time, access to long-term funding is paramount. There also is a need to reconcile the slow pace of scholarly work with the rapidly moving terrain of commodity networks.

While these challenges illustrate the limitations of our approach, they do not invalidate its potential. When we began our work, participating communities had no voice in the broader 
rooibos network. During preliminary forays into network events, the leaders spoke among themselves and were largely ignored by higher level actors. By project end, key representatives had come to recognize the leaders as professionals with knowledge to share, pointing to a critical shift in relations. Finally, the skills that we developed during this project have delivered ongoing benefits. Some of the leaders have continued to support their communities by navigating avenues for assistance. Others have managed to secure formal employment in a nation where unemployment rates are high and growing (Ebrahim, Leibbrandt, \& Woolard, 2015). A number of industry actors remain involved with small-scale farmers, and one who was closely involved in our project has expressed an ongoing commitment to collaborative inquiry. We also have become more adept at ensuring spaces for reflexive dialogue and multidirectional learning.

While our experiences clarify the challenges involved in extending participation to multilateral networks, PCNR offers tangible solutions to the challenges facing social justice in trade. As Fairtrade markets continue to grow, there is mounting concern regarding the quality of engagement with marginal groups (Raynolds \& Bennett, 2015). Our research substantiates these concerns. Yet, despite the turmoil surrounding Fairtrade in rooibos, we found that most farmers continued to want access to certified markets. Indeed, Fairtrade's minimum pricing guarantees and social premiums were viewed as critical to small farmers who could not secure viable pricing from conventional markets. The decentralization of producer services to Fairtrade's regional affiliates offers a critical opportunity to address gaps in support and action research is well suited to this task. That said, it is important to note that Fairtrade is not the only entry point. As a variety of ethically labeled items expand their entry into domestic as well as global markets (Hughes et al., 2015), PCNR may provide farmers with an opportunity to evaluate and choose livelihood strategies that best fit their needs.

\section{Conclusion}

This article has presented PCNR within the context of a one-year project with smallscale rooibos tea farmers. Our work uncovered grave issues related to producers' experiences with Fairtrade. In seeking to upgrade their rooibos value via a certified packaging venture, small-scale farmers were exposed to risk and experienced a period of crisis that led to the collapse of a large cooperative. Not only did members possess little understanding of Fairtrade markets, they had limited access to information and felt alienated from available sources of assistance. We responded to their concerns by involving farmer leaders in a participatory research, training, and networking program. As Fairtrade International shifts governance of producer services to its affiliates, our approach may inform the development of collaborative support mechanisms.

This article also offers critical insights for scholars and professionals who are interested in democratizing participation in development (Mohan, 2001). Our experience clarifies the challenges facing marginal groups as well as the extent of engagement that is needed to open spaces where empowered actions can occur. Professional networking is an appropriate starting point, but opportunities for informal engagement are essential. In our case, informal interactions enabled us to develop trust and overcome limitations. As power 
and identity are deeply embedded in our ways of knowing and being, we encourage researchers to remain open to the inquiry (EAC, 2005). Similarly to others who have studied inequities in postcolonial research and practice, we believe that participatory approaches offer "transformative potential" but only if these remain "power-sensitive and self-critical” (Schurr \& Segebart, 2012, p. 152).

Finally our approach meets a gap in PAR as it provides an actionable methodology for extending participation to the wider processes of development (Chevalier \& Buckles, 2013). It links PAR with commodity network analysis to open a platform for multilateral engagement. While we were unable to ensure equal participation in all that we did, we navigated tensions related to scalability by placing farmer leaders at the center of action. Our engagement ultimately enabled the leaders to assume positions of authority in a policy seminar that they designed and facilitated. Due to time and resource barriers, we were unable to extend this platform through sustained inquiry. However, the potential for humanizing production and trade relations remains. PCNR met the preliminary test of action by providing small-scale farming communities with an opportunity to build leadership and communicate concerns during a time of urgency.

\section{Authors' note}

Stakeholders involved a team of farmer leaders, small-scale rooibos producers, and various industry and organizational groups. Not only did participants enable us to devise an integrated framework for research and support, the farmer leaders played a central role in developing our approach. We have sought to capture their contributions, but retain responsibility for the views presented in this article.

\section{Acknowledgement}

We would also like to thank Dr. Patricia Gaya for leading the review process of this article. Should there be any comments/reactions you wish to share, please bring them to the interactive portion of our blog on the associated $\mathrm{AR}+\mid$ ActionResearchPlus website: http:// actionresearchplus.com.

\section{Declaration of Conflicting Interests}

The author(s) declared no potential conflicts of interest with respect to the research, authorship, and/or publication of this article.

\section{Funding}

The author(s) disclosed receipt of the following financial support for the research, authorship, and/or publication of this article: The project was funded by the Horticulture Collaborative Research Support Program (HortCRSP grant number 09-002945-10). 


\section{Notes}

1. The term "fair trade" refers to the movement and "Fairtrade" denotes the certification network as governed by Fairtrade International.

2. Instituted in 2005, Fairtrade Africa is based in Nairobi and represents more than

700,000 certified farmers and workers (Fairtrade Africa, 2014).

3. One elected farmer leader was a white male who had married into a coloured community.

4. The board of one organization declined involvement on behalf of its members.

5. An elected farmer leader was a staff member of the decertified cooperative and three other leaders led producer associations.

6. Names have been changed to protect the identity of individuals.

7. We completed 58 farmer interviews with 44 of these deriving from a stratified random sample.

8. Prior to this stage, potentially relevant power dimensions were collectively identified to help frame interview questions and analysis. During data analysis, the importance of each dimension was determined by vote and consensus when possible.

9. One female leader was talked into the leadership position by elders in her community after attempting to decline her nomination. By project end, she had become a confident researcher and public speaker.

10. Brown people. 


\section{References}

Brydon-Miller, M., Greenwood, D., \& Maguire, P. (2003). Why action research? Action Research, 1, 9-28.

Chambers, R. (1994). Participatory rural appraisal (PRA): Challenges, potentials and paradigm. World Development, 22, 1437-1454.

Chevalier, J. M., \& Buckles, D. (2013). Participatory action research: Theory and methods for engaged inquiry. New York: Routledge.

Ebrahim, A., Lebbrandt, M., \& Woolard, I. (2015). Strategies of the unemployed in South Africa: Does moving allow the unemployed to get ahead? A Southern Africa Labour and Development Research Unit Working Paper Number 157. Cape Town, South Africa: University of Cape Town.

EAC [European American Collaborative Challenging Whiteness]. (2005).

European American Collaborative Challenging Whiteness. (2005). Reflections on Erica Gabrielle Foldy's first-person inquiry. Action Research, 3, 55-61.

Fairtrade Africa. (2014). Who we are. Retrieved July 27, 2014, from http://www.fairtradea- frica.net/about-us/who-we-are/

Fairtrade International. (2013). Unlocking the power: Annual report 2012-13 (pp. 120). Bonn, Germany: Author.

Fairtrade International. (2014). Strong producers, strong future: Annual report 20132014 (pp. 1-24). Bonn, Germany: Author.

Freire, P. (1997). Pedagogy of the oppressed, 20th Anniversary Edition. New York, NY: Continuum Publishing.

Gereffi, G. (1994). The organization of buyer-driven global commodity chains. In G. Gereffi, \& M. Korzeniewicz (Eds.), Commodity chains and global capitalism (pp. 95-122). Westport, CT: Praeger.

Gibbon, P., \& Ponte, S. (2005). Trading down: Africa, value chains, and the global economy. Philadelphia, PA: Temple University Press.

Hoffmann, V., Probst, K., \& Christinck, A. (2007). Farmers and researchers: How can collaborative advantages be created in participatory research and technology develop- ment? Agriculture and Human Values, 24, 355-368.

Hughes, A., McEwan, C., \& Bek, D. (2015). Mobilizing the ethical consumer in South Africa. Geoforum, 67, 148-157.

Ives, S. (2014). Farming the South African "bush": Ecologies of belonging and exclusion in rooibos tea. American Ethnologist, 41, 698-713.

Keahey, J. (2015). Fair trade and racial equity in Africa. In L. T. Raynolds, \& E. A. Bennett (Eds.), Handbook of research on fair trade (pp. 441-456). Northampton, MA: Edward Elgar Publishing.

Keahey, J. (2016). Whose knowledge counts? Developing fair trade skills in South Africa. Globalizations, 13, 409-424.

Mkabela, N. Q., \& Luthuli, P. C. (1997). Towards an African philosophy of education. Pretoria, South Africa: Kagiso.

Mohan, G. (2001). Beyond participation: Strategies for deeper empowerment. In B. Cooke, \& U. Kothari (Eds.), Participation: The new tyranny? (pp 152-167). London, England: Zed Books. 
Naylor, L. (2014). "Some are more fair than others": Fair trade certification, development, and North-South subjects. Agriculture and Human Values, 31, 273-284.

Neef, A., \& Neubert, D. (2011). Stakeholder participation in agricultural research projects: A conceptual framework for reflection and decision-making. Agriculture and Human Values, 28, 179-194.

Nelson, V., \& Martin, A. (2015). Fairtrade International's multi-dimensional impacts in Africa. In L. T. Raynolds, \& E. A. Bennett (Eds.), Handbook of research on fair trade (pp. 509-531). Northampton, MA: Edward Elgar.

Nemeroff, T. (2008). Generating the power for development through sustained dialogue: An experience from rural South Africa. Action Research, 6, 213-232.

Nussbaum, M. C. (2011). Creating capabilities. Cambridge: Harvard University Press.

Phillips, D. (2014). Uneven and unequal people-centered development: The case of fair trade and Malawi sugar producers. Agriculture and Human Values, $31,563-576$.

Ponte, S., \& Ewert, J. (2009). Which way is "up" in upgrading? Trajectories of change in the value chain for South African wine. World Development, 37, 1637-1650.

Raynolds, L. T. (2009). Mainstreaming fair trade coffee: From partnership to traceability. World Development, 37, 1083-1093.

Raynolds, L. T., \& Bennett, E. A. (2015). Introduction to research on fair trade. In L. T. Raynolds, \& E. A. Bennett (Eds.), Handbook of research on fair trade (pp. 3-23). Northampton, MA: Edward Elgar.

Raynolds, L. T., \& Keahey, J. (2014). Fair trade: Social justice and production alternatives. In M. Parker, G. Cheney, V. Fournier, \& C. Land (Eds.), The Routledge companion to alternative organization (pp. 165-181). New York, NY: Routledge.

Raynolds, L. T., \& Ngcwangu, S. U. (2010). Fair Trade rooibos tea: Connecting South African producers and American consumer markets. Geoforum, 41, 74-83.

Schurr, C., \& Segebart, D. (2012). Engaging with feminist postcolonial concerns through participatory action research and intersectionality. Geographica. Helvetica, 67, 147-154.

Selener, D. (1997). Participatory action research and social change. Ithaca, NY: The Cornell Participatory Action Research Network.

Sen, A. (2004). Capabilities, lists and public reason: Continuing the conversation. Feminist Economics, 10, 77-80.

Smith, A. (2009). Fair trade, diversification and structural change: Towards a broader the- oretical framework of analysis. Oxford Journal of Development Studies, 37, 457-478.

Tallontire, A. (2015). Fair trade and development in African agriculture. In L. T. Raynolds, \& E. A. Bennett (Eds.), Handbook of research on fair trade (pp. 372387). Northampton, MA: Edward Elgar.

WFTO \& FTI [World Fair Trade Organization \& Fairtrade International]. (2009). 
World Fair Trade Organization \& Fairtrade International. (2009). A charter of fair trade principles. Retrieved June 12, 2015, from http://www.fairtradeadvocacy.org/images/Charter_of_Fair_Trade_principles_EN_v1.2.pdf 